O. F. Piminov, L. I. Shulga, S. I. Trutaiev, K. O. Burian

National University of Pharmacy

\title{
INTRODUCTION OF DISTANCE LEARNING IN THE POST-GRADUATE PHARMACEUTICAL EDUCATION: POSSIBILITIES, PROBLEMS, ADVANTAGES
}

The conditions of implementation of distance learning in the system of the postgraduate education of the pharmacy specialists have been investigated. The results of the survey revealed that the technical capabilities of pharmacy specialists is insufficient to conduct distance courses, the survey also discusses the limited access to information resources and the desire to have direct communication with teachers. It is expedient to introduce the elements of distance learning technologies in the postgraduate training of pharmacists as the initial stage of the transition to distance education services.

Key words: distance education; postgraduate education; pharmacy; sociological research

\section{STATEMENT OF THE PROBLEM}

For the last decades in educational sphere the cardinal changes are noted, among them the introductions of innovative forms of study, to which by general signs it is possible to take distance learning. It is determined that today, getting higher education on speciality, a specialist does not have a "inflexible block" of knowledge for the further professional activity for the whole life. This fact is supported by the statistics about an annual update near $25 \%$ of knowledge. Alternate version is passing to the continuing education, in which base education is not eventual from the beginning, but only as the foundation for knowledge accumulation. The purpose of educational process is being changed, programs are being updated, approaches to learning are being transformed. Considering the leading global trends, the modern pharmacist has to be oriented both in the field of professional knowledge and in the informative field. Thus, a specialist today must have professional training in the branch of pharmacy, using as time-tested standardized methods, and modern innovative ones [1, 3, 4, 8].

\section{ANALYSIS OF RECENT RESEARCH AND PUBLICATIONS}

Today distance learning is one of the declared forms of educational activity that peculiar attributes of ordinary educational process, progressive type of studies based on modern informatively-communication technologies [5]. Efficiency of distance

(c) Trutaiev S. I., Piminov O. F., Shulga L. I., Burian K. O., 2016 learning is to teach users of this educational service independently of geographical location of the universities, by their own schedules, in convenient time, purposefully and proactively.

The introduction of distance learning is the subject of studies which are conducted by both domestic and foreign scientists and involves different sectors of science and practice. Much attention is paid to the technological capabilities of remote support process, visual programming, creation of virtual environments [2, 3, 9-15].

\section{IDENTIFICATION OF ASPECTS OF THE PROBLEM UNSOLVED PREVIOUSLY}

Nowadays distance learning becomes the main form of status of Postgraduate education: the advantages of distance form for professional training of pharmacists on the base of network technologies and on-line have been noted. But the willingness of primary audience to promote qualification on speciality with this progressive form is not enough reflected.

\section{OBJECTIVE STATEMENT OF THE ARTICLE}

To define possibilities of listeners to introduce distance learning in postgraduate pharmaceutical education, highlights the existing problems and outline the ways of their.

\section{PRESENTATION OF THE MAIN MATERIAL OF THE RESEARCH}

The complex of interrelated methods in research is used: supervision, conversations and question- 
naires. Research was conducting during 2014 among the listeners of the courses of training specialists of pharmacy in Ukrainian towns: Poltava, Odessa, Chernihiv, Chernivtsi. The general quantity of respondents was 220 persons. All questionnaires with answers were analyzed and treated.

To study the possibility of distance learning courses in post-graduate education of pharmacy specialists, to the listeners of cycles of training was given representation of course with following questioning on our own developed questionnaire to study the desire in the future to improve their skills while studying distance learning and in offwork hours (or part-time) by their own schedule to capture material.

The presentation project of distance course contains: information about authors, structure of interface, algorithm of studying, structure of theoretical and practical material, and types of tasks with explanations to criteria of registration, implementation and evaluation, explanation in what way to realize test tasks to each theme and in a final control.

To the pilot variant of questionnaire which was developed and offered to the listeners in Poltava, the block of general questions was put for the receipt the information about respondents (age, seniority, the post) and block from 12 special questions which were formulated in the opened, closed and opposite forms.

At the analysis of questionnaires it has been discovered that the main part of listeners did not give answer for the opened questions, and it was difficult to systematize questionnaires which contained answers. Therefore, for the further information gathering, a questionnaire was improved by use the closed and opposite questions only, and a point about the knowledge of operating systems and programs was deleted at all.

Considering the result obtained, a target audience has been chosen. It is a basic contingent, which is open for a communication that wish the changes, shows interest in new, ready to self-training and collaboration. We noted the prevailing group of listeners is of age from 41 to 60 years and seniority up to 30 years. According respondents labor duties, they are the majority pharmacists that hold the position of manager of drugstore $(41 \%)$, the pharmacists (34\%) and druggists (25\%). At the same time we expected that the most listeners, there are interested in distance learning, must have had age from 20 to 40 years old, which are more often apply information technologies in everyday life. In addition, working group aged 20 to 40 years approximately less than age group from 41 to 60 , which is associated with passing the nearest courses of training and improving professional skills since graduation and study in an internship, that are listeners older than 25 years. It should be noted that some tested questionnaires have had not all answers for the offered questions, which is why there is an amount of answers, which does not answer $100 \%$.

The basic questions of questionnaire are contained 11 points. By the content they can be divided into two categories: the category 1 relates to the exposure economic feasibilities of listeners, as for the category 2, which shows the listeners' level of use world network in the Internet and desire to get knowledge from distance learning. A residence of most listeners in cities is precondition of anymore probability of presence of access and use the Internet, 79,5\% respondents are confirmed this statement. However the Internet is not yet solve the problem of mass use of distance learning, in view of the fact that out of 220 respondents only $65,9 \%$ have access to personal computer home, 47,2\% at work and 6,3\% does not have such opportunity at all.

It is also necessary to take into account that the use of computer at work is possible but can make a negative attitude of the leadership in the case of systematic, daily and long time use (the course program recommends about 3 hours a day).

To identify the personal confidence of listeners in using a personal computer the questions are offered with the definition of user level after the selfrating (high, medium, low). More than $50 \%$ of the participants give the answer that they evaluate their level as medium, being able to work in the program «Word». Foreseeing the difficulties of users of distance course in connection with the performance of tasks in unknown program "Moodle", suggested written tasks in more familiar and comfortable program "Word" with the subsequent departure by a lecturer e-mail. It is comfortable to use e-mail for a feedback with a lecturer, which is available only for $55,9 \%$ of the respondents.

Thus, the received data show that at least $65,9 \%$ of the interviewed person technically is able to take on-line courses and improve their skills. The summary statistics regarding listeners' technical capabilities are summarized in Table 1.

Another part of the questionnaire, the special one, was offered to listeners for study application of modern technologies in order to get information, using internet-resources and taking part in improving the professional skills on-the-job.

The availability of practical skills using the Internet in daily life, besides the social networks, in order to facilitate the process of distance learning. Almost $40 \%$ of respondents noted that they use the resources of the Internet regularly. Practically 
INFORMATION ABOUT THE AVAILABILITY OF THE TECHNICAL CAPABILITIES OF PHARMACISTS

\begin{tabular}{|c|c|c|c|c|c|c|}
\hline \multirow{2}{*}{$\begin{array}{l}\text { Investigated } \\
\text { index, } \%\end{array}$} & \multirow{2}{*}{ Answer } & \multicolumn{4}{|c|}{ Town } & \multirow{2}{*}{ Tota } \\
\hline & & Poltava & Odesa & Chernivtsi & Chernihiv & \\
\hline \multirow{3}{*}{$\begin{array}{l}\text { Permanent } \\
\text { residence }\end{array}$} & town & 22,7 & 25,9 & 6,4 & 11,8 & 66,8 \\
\hline & $\begin{array}{l}\text { urban-type } \\
\text { settlement }\end{array}$ & 6,8 & 1,4 & 0,9 & 2,7 & 11,8 \\
\hline & village & 8,6 & 0,4 & 7,7 & 1,4 & 18,1 \\
\hline \multirow{3}{*}{$\begin{array}{l}\text { Access to the use } \\
\text { of PC for personal } \\
\text { purposes }\end{array}$} & at home & 22,3 & 21,8 & 9,1 & 12,7 & 65,9 \\
\hline & at work & 14,5 & 18,2 & 5,4 & $9 Д$ & 47,2 \\
\hline & no & 1,8 & 0,9 & 2,7 & 0,9 & 6,3 \\
\hline \multirow{3}{*}{$\begin{array}{l}\text { Assessment of one's } \\
\text { own level computer } \\
\text { skills (or PC) }\end{array}$} & high & - & 2,3 & 0,4 & 0,9 & 3,6 \\
\hline & medium & 17,3 & 20,0 & 9,1 & 10,4 & 56,8 \\
\hline & low & 7,7 & 5,0 & 5,4 & 5,0 & 23,1 \\
\hline \multirow{2}{*}{$\begin{array}{l}\text { Skills of work } \\
\text { in programs }\end{array}$} & Word & 13,6 & 19,1 & 9,1 & 10,0 & 51,8 \\
\hline & Excel & 12,3 & 15,0 & 2,3 & 5,4 & 35,0 \\
\hline \multirow{2}{*}{$\begin{array}{l}\text { Availability } \\
\text { the Internet }\end{array}$} & yes & 28,6 & 25,4 & 12,3 & 13,2 & 79,5 \\
\hline & no & 11,8 & 1,8 & 2,7 & 3,6 & 19,9 \\
\hline \multirow{2}{*}{ E-mail } & yes & 15,4 & 23,2 & 6,4 & 10,9 & 55,9 \\
\hline & no & 21,8 & 4,5 & 8,6 & 5,4 & 40,3 \\
\hline
\end{tabular}

the same indicate $(38,2 \%)$ has a group of respondents who chose the answer "seldom". But a fifth of respondents are not familiar with expressed activity. The next question focused on using the Internet. The answers were difficult to interpret, because the most of respondents chose 2 or even 3 suggested versions. However, as things turned out, what the listeners exactly mean working aim, the respondents were singled implementation of standard working procedures, using of which is impossible without the Internet.

$60,4 \%$ of respondents take «live» communication (informal interaction) with a lecture, in relation of importance a direct communication of a listener and a lecturer, i.e. having lectures, practi-

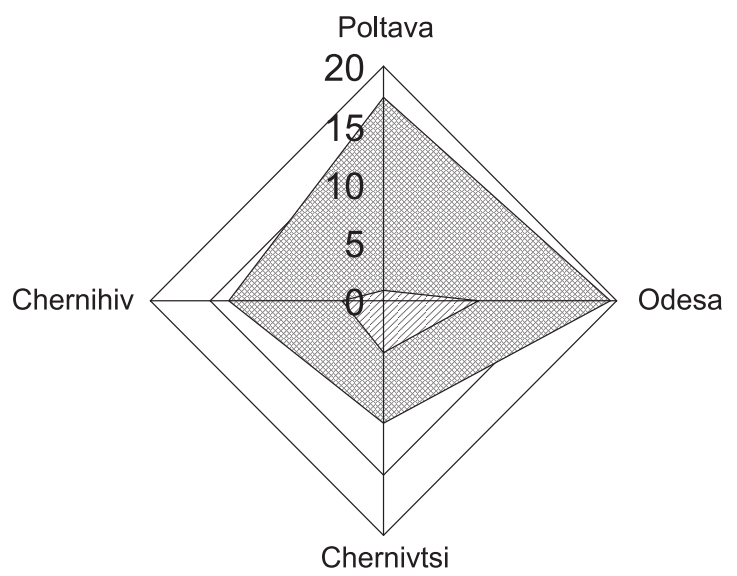

The priority of communication with a lecturer (\%) Yes The priority of communication with a lecturer (\%) No

Fig. 1. The importance of direct communication of a listener and a lecturer cal exercises and seminars in standard form to date (Fig. 1). About $20 \%$ of listeners gave no answer to this question.

In relation to participating in the project «University - distance learning on-line», almost all respondents answered that did not take part in this project, although at least one pharmacist from every city used this opportunity. This low number is due to the motivation to participate - successfully passed every unit test lecture is accompanied by a certificate, which gives one point to a respondent to get the category (according to the scale of values of the different activities of pharmacists in the period between the qualification cycles). We have identified an interest to participate in the project more pharmacists who is recommended to recruit the necessary number of points depending on the type categories in the period between the qualification cycles. The motivation for the participation of others specialists of pharmacy was only getting personal knowledge and self-control. The summarized data are given in Table 2.

The last question of questionnaire concerned the personal desire of listeners to participate in the following training courses of distance learning. The results of study this question presented in Fig. 2.

Obviously, the majority of students (over $60 \%$ ), wishes to take courses of improving professional skills on distance learning. But among them there are some listeners who reported about absence of the Internet or PC, that makes it impossible to conduct distance learning courses. In general, the information that we have received can be attributed to answers well thought out that take the positive 


\section{INFORMATION ABOUT THE USE OF THE INTERNET AND THE DESIRE OF STUDENTS TO GAIN KNOWLEDGE THROUGH DISTANCE LEARNING}

\begin{tabular}{|c|c|c|c|c|c|c|}
\hline \multirow{2}{*}{$\begin{array}{c}\text { Investigated } \\
\text { index, \% }\end{array}$} & \multirow{2}{*}{ Answer } & \multicolumn{4}{|c|}{ Town } & \multirow{2}{*}{ Total } \\
\hline & & Poltava & Odesa & Chernivtsi & Chernihiv & \\
\hline \multirow{3}{*}{$\begin{array}{l}\text { The frequency of using the } \\
\text { resources on the Internet } \\
\text { network }\end{array}$} & regularly & 8,2 & 19,5 & 5,4 & 7,3 & 40,4 \\
\hline & seldom & 17,3 & 6,8 & 7,7 & 6,4 & 38,2 \\
\hline & never use & 13,2 & 1,8 & 1,8 & 3,6 & 20,4 \\
\hline \multirow{3}{*}{$\begin{array}{l}\text { The purpose of using the } \\
\text { Internet resources }\end{array}$} & for private use & 5,0 & 18,6 & 8,6 & 10,9 & 43,1 \\
\hline & for work & 7,3 & 20,9 & 5,9 & 8,6 & 42,7 \\
\hline & self-training & 5,0 & 15,9 & 4,1 & 8,6 & 33,6 \\
\hline \multirow{2}{*}{$\begin{array}{l}\text { The participation in the } \\
\text { project «University is the } \\
\text { distance learning on-line» }\end{array}$} & yes & 0,4 & 0,9 & 0,9 & 0,4 & 2,6 \\
\hline & no & 32,3 & 26,4 & 12,7 & 16,4 & 87,8 \\
\hline
\end{tabular}

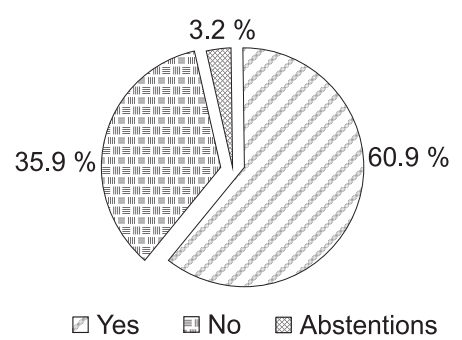

Fig. 2. A personal desires of students to pass courses of improvement of qualification

in the distance learning system

attitude of listeners towards obtaining new knowledge in modern teaching methods.

\section{CONCLUSIONS}

The attitude of pharmacy specialists to distance learning services has been investigated. The state of technical possibilities and personal listeners' desire to take the courses of improving professional skills on distance learning has been presented. These questionnaires have testified that $65.9 \%$ of listeners have access to use $\mathrm{PC}$ in their own aims, $79.5 \%$ have the opportunity use the Internet resources and $60.9 \%$ are willing to take the courses of improving professional skills on-line.

It has been set that more complete access to informative resources as a fact is indisputable, but the listeners have doubts about the quality of distance learning services, which are expressed in form of distrust computer systems and the desire to communicate directly with a lecturer.

In view of the given above, the complete passing to the courses of improving professional skills of distance form of learning, as appeared, is difficult to do. We believe that the process of implementation of distance learning should be gradual, it needs implementation with the full-time course of study, the so called distance elements, with giving listeners a chance of an alternative form to improve their professional level.

\section{REFERENCES}

1. Белозубов А. В. Система дистанционного обучения «Moodle» : [учеб.-метод. пособие] / А. В. Белозубов, Д. Г. Николаев. - С.Пб., 2007. - 108 с.

2. Белявский О. В. Содержание образовательной программы цикла повышения квалификации «Организационные и методические аспекты внедрения системы «Moodle» в образовательный процесс медицинского университета» / О. В. Белявский, Г. Г. Синьков // Образование XXI века : сб. матер. Междунар. науч.-практ. конф. - Витебск : ВГМУ, 2014. - С. 282-284.

3. Дистанційне навчання: психологічні засади : [монографія] / [М. Л. Смульсон, Ю. І. Машбиць, М. І. Жалдак та ін.] ; за ред. М. Л. Смульсон. - Кіровоград : Імекс-ЛТД, 2012. - 240 с.

4. Карпенко М. Освіта протягом життя : світовий досвід і українська практика / М. Карпенко // Аналітична записка. Національний інститут стратегічних досліджень при Президентові України. - Режим доступу : http:// www.niss.gov.ua/articles/252/

5. Колосов В. И. Оптимизация образовательного процесса с применением дистанционных форм обучения / В. И. Колосов // Междунар. журн. эксперимент. образования. - 2010. № 11. - С. 155-157.

6. Оптимизация высшего фармацевтического образования в Днепропетровской медицинской академии / [В. И. Гарец, И. И. Колосова, И. И. Кононова и др.] // Образование XXI века : сб. матер. Междунар. науч.-практ. конф. - Витебск : ВГМУ, 2014. - С. 293-295.

7. Черних В. П. Університет - дистанційна освіта on-line / В. П. Черних, О. Ф. Пімінов // Аптека on-line. - 2012. - № 35. - Режим доступу : http://www.apteka.ua/article/159872.

8. Afsaneh Towhidi. Distance Education Technologies and Media Utilization in Higher Education / T. Afsaneh // Intern. J. of Instructional 
Technol. and Distance Learning. - 2010. Vol. 7, № 8. - P. 3-30.

9. Dal Bello A. Interactive videoconferencing as a medium for special education; knowledge acquisition in preservice teacher education / A. Dal Bello, E. Knowlton, J. Chaffin // Intervention in School \& Clinic. - 2007. - Vol. 43, № 1. - P. 38-46.

10. Dennen V. P. Instructor-learner interaction in online courses: The relative perceived importance of particular instructor actions on performance and satisfaction / V. P. Dennen, A. A. Darabi, L. J. Smith // Distance Education. - 2007. - Vol. 28, № 1. - P. 65-79.

11. Gujjar A. A. Preparation of instructional material for distance teacher education / A. A. Gujjar, M. A. Malik // Turkish Online J. of Distance Education. - 2007. - Vol. 8, № 1. - P. 55-63.
12. Luppicini R. A. Systems Definition of Educational Technology in Society / R. A. Luppicini // Educational Technology \& Society. - 2005. - Vol. 8, № 3. - P. 103-109.

13. Simonson M. Theory and distance education: A new dimension / M. Simonson, C. Schlosser, D. Hanson // Am. J. of Distance Education. 2000. - Vol. 13, № 1. - P. 60-75.

14. $\mathrm{Su}$ B. The importance of interaction in web-based education: A program-level case study of online MBA courses / [B. Su, C. J. Bonk, R. J. Magjuka et al.] // J. of Interactive Online Learning. - 2005, Vol. 4, № 1. - P. 1-18.

15. Wise R. Multimedia: a critical introduction / R. Wise, J. Steemers. - London, NY: Routledge, 2000. $-228 \mathrm{p}$. 


\section{УДК 615.1:378.147:378.046-021.68:001.891}

А. Ф. Пиминов, Л. И. Шульга, С. И. Трутаев, Е. А. Бурьян

ВНЕДРЕНИЕ В ПОСЛЕДИПЛОМНОЕ ФАРМАЦЕВТИЧЕСКОЕ ОБРАЗОВАНИЕ ДИСТАНЦИОННОГО ОБУЧЕНИЯ: ВОЗМОЖНОСТИ, ПРОБЛЕМЫ, ПРЕИМУЩЕСТВА

Исследованы предпосылки внедрения дистанционного обучения в систему последипломного образования специалистов фармации. Анкетированием слушателей курсов повышения квалификации доказано недостаточность технических возможностей специалистов фармации, ограниченность доступа к информационным ресурсам и желательность непосредственного общения с преподавателями. Установлена целесообразность внедрения элементов дистанционных технологий в последипломной подготовке провизоров и фармацевтов как начальной стадии перехода на дистанционное предоставление образовательных услуг.

Ключевые слова: дистанционное обучение; последипломное образование; фармация; социологические исследования

УДК 615.1:378.147:378.046-021.68:001.891

О. Ф. Пімінов, Л. І. Шульга, С. І. Трутаєв, К. О. Бур'ян ВПРОВАДЖЕННЯ В ПІСЛЯДИПЛОМНУ ФАРМАЦЕВТИЧНУ ОСВІТУ ДИСТАНЦІЙНОГО НАВЧАННЯ: МОЖЛЛВОСТІ, ПРОБЛЕМИ, ПЕРЕВАГИ

Досліджені передумови впровадження дистанційного навчання в систему післядипломної освіти спеціалістів фармації. Анкетуванням слухачів курсів підвищення кваліфікації доведено недостатність технічних можливостей фахівців фармації, обмеженість доступу до інформаційних ресурсів та бажаність безпосереднього спілкування з викладачами. Встановлено доцільність впровадження елементів дистанційних технологій у післядипломній підготовці провізорів і фармацевтів як початкової стадії переходу на дистанційне надання освітніх послуг.

Ключові слова: дистанційне навчання; післядипломна освіта; фармація; соціологічні дослідження

Адреса для листування:

61001, м. Харків, пл. Повстання, 17.

Тел. (057) 732-27-98.

E-mail: farmtex-ipksf@nuph.edu.ua.

Національний фармацевтичний університет
Надійшла до редакції 11.01.2016 p. 